\title{
Situating language at the centre of journalism training: The case for broadening the spheres of English teaching and learning in Journalism training institutions in Ghana
}

\author{
Modestus Fosu
}

\begin{abstract}
This paper derives its impetus from the consensus today that the media play an indispensable role in democratic governance for sustained development. The media foster, most importantly, accountability, transparency, rule of law, respect for human rights, and civic participation, which are vital in securing the economic well-being of a people. Language, as the main vehicle that drives communication or journalistic imperatives to the "consumer", thus becomes a critical factor.

The focus here is on the effective and appropriate use of English (Ghana's official language) in newspapers in Ghana. It is argued that the majority of newspapers display linguistic ineptitude, thereby weakening their capacity to package and make development-oriented messages accessible to the reader. Specifically, the majority of newspapers present news in grammatically faulty and semantically confusing constructions that blur meaning. Thus, through a comparative study of the English and English-related courses in four journalism training institutions in Ghana and the English provisions in the latest UNESCO journalism curricula for Africa (2007), the study shows that English competence appears to be taken for granted in the training institutions.
\end{abstract}

This paper therefore argues for journalism education in Ghana to focus on helping trainee journalists to acquire English language competency. A more worthwhile complement will be to de-emphasise the 
"core" journalism or media knowledge and skills students are made to focus all their attention on in the schools and rather emphasise English use and usage. The paper suggests a reorganisation of English studies including institutional structure, curriculum and syllabus development, infrastructure, teaching, and learning methodology as ways of broadening English language pedagogy to produce the calibre of journalists who can really champion the democratic and developmental aspirations of Ghana and Africa.

\section{Introduction}

The objective of this paper is two-fold. The first is to emphasise the ongoing problem of English usage, particularly in writing, in Ghanaian newspapers. The second aim is to argue that journalism institutions need to do more to improve the journalistic capacity for English through a reorganisation of English training in journalism schools in Ghana. The paper sets forth from the perspective that the media has a crucial role to play in a democracy to enhance socio-economic and political participation and development. Press theory and democratic theory (see McQuail, 2005) both acknowledge the functional role of the press in a democracy. The press enhances governance through the provision of and dissemination of local, national, and international information to help citizens build their knowledge base to constitute a viable public sphere of political and social discourse. The UNESCO Model Curricula for Journalism Education (2007: 6) captures the Media's role more succinctly:

As a source of information, analysis and comment on current events, journalism performs a number of functions in modern societies. The basic goal of most journalists, however, is to serve society by informing the public, scrutinizing the way power is exercised, stimulating democratic debate, and in those ways aiding political, economic, social and cultural development.

Through the above, citizens can transform themselves and through that transform their environment. It is becoming increasingly clear that development goes beyond national economic indices such as GDP. According to Okigbo (2004: 39), development necessitates "attention ... 
to a myriad of social and cultural issues, many of which involve the creation and management of knowledge". This paper, therefore, posits that national development should manifest in the ability of a nation and its people to position themselves to take advantage of opportunities within the nation and beyond for holistic progress. In view of the imperatives of development, there is the need for the press in a developing environment like Ghana to make information and knowledge available to citizens for empowerment (see Melkote \& Steeves, 2010). According to the former Secretary General of the United Nations, Kofi Annan, "if information and knowledge are central to democracy, they are the conditions of development" (http://www.rdfs.net/themes/communication_en.htm).

The Ghanaian media today comprise over 70 registered and active newspapers (National Media Commission, Ghana, 2009), 171 radio stations, and 15 free-to-air and encrypted TV stations ( National communication Authority, Ghana, 2009) scattered all over the country. Apart from being a constructed historical and social mirror of a people, the media also command a great influence, an influence that can lead to social change for development. It is because of such a normative and functional role (McQuail, 2005) that the language of the press ought to be suitable to attract reading and readership.

This work focuses more on media writing in English and tilts towards newspapers in Ghana. This is not to imply that English used on the electronic media is without problems. Indeed, whereas newspapers have the benefit of the production chain such as editing, proofreading, etc., the radio, for example, is often a largely instantaneous occurrence and recurring language problems on the airwaves can have a negative impact on listeners in many ways. Therefore, the language of the electronic media offers a huge potential for in-depth study, which other full-scale research can focus on.

However, as a preliminary study, this work dwells on the English in Ghanaian newspapers. This focus is because of the remarkable aspect of language problems in print media in spite of the checks and balances in the production processes. Additionally, as Hasty (2005: 2) notes, 
"Newspapers form the nexus of this news discourse in Ghana". Newspapers, in fact, constitute a significant source of public information for much of the social and political discussions in the country. Moreover, newspapers serve as a relatively more immediate physical reference material for study, especially in schools.

Language is central to journalism as it serves as the main vehicle that drives communication or journalistic imperatives to the 'consumer.' The linguistic situation in Ghana presents an interesting scenario where, in spite of the over 60 indigenous languages, English remains the official and national language. Remarkably, almost all the newspapers in Ghana are published in English (Ghana Media Commission, 2009). The implication is that if Ghanaians must be informed through newspapers, then they must be able to read and understand the English used in this medium.

\section{The problem of English in the Ghanaian print media}

Media freedom and pluralism today have been unparalleled in Ghana's history. This follows the political stability and the relatively and progressively liberal press environment the country has enjoyed since 1993. This should be good news for Ghana, a nation, like many of her neighbours in Africa, in need of economic and political advancement. Nevertheless, the question remains as to how effectively the press is using language to enhance the gains expected of journalism.

The problem has been that newspapers in Ghana appear not to really "communicate". Almost all the papers appear to display challenges in English, thereby weakening their capacity to appeal to and reach their supposed readers. News is often presented in faulty, confusing, and sometimes complex grammatical constructions that could interfere with reading and understanding (Fosu, 2009). Academia and the media in Ghana have been bombarded with complaints of poor and/or inappropriate English in the media. An article by Nii Moi Thompson, a renowned economist and writer, sums up the numerous cries against poor English in the media in one of Ghana's leading newspapers. He noted that: 
For the print media, overall writing quality is poor ... most other journalists seem content with their own badly written stories, thus repeating common mistakes in grammar and spelling and pushing the profession further down the tubes.

The writer cited some of these "common mistakes" and offered some remedies. However, the situation has not changed; it appears to get worse by the day.

It would appear that Anglophone Africa is homogeneous on this disturbing issue of poor English in the media. Edward Chitsulo (2009) of the University of Malawi has made a similar assessment of Malawian newspapers. In a paper presented at the Conference of African Journalism Educators (CAJE) in Johannesburg, South Africa, he gave some startling examples of such faulty and often confounding English expressions. He emphasised that, "The media industry in Malawi has lately manifested a degree of malaise in delivery -- especially in writing in English and Chichewa, the official languages" (http://www.journalism.co.za./image/april2009/languages).

Additionally, the issue of poor English among students and graduates from tertiary institutions in Ghana has received much scholarly attention. For example, Dako, Denkabe \& Forson (1997) in a study of university students' knowledge of English grammar noted that their work was prompted by “... our observation over the years of a steady decline in the English competence of products of our schools and universities. This has caused concern to be expressed especially among experts and the general public" (p. 53). Fosu (2009: 22), in an article on English in tertiary institutions, categorised some of the problems as follows:

Grammatical shortfalls, such as faulty application of concord, tense use, pronoun and prepositional use, article use, among others, in speaking and writing Incorrect spelling Incorrect pronunciation and intonation Ambiguous sentences that do not communicate well 
Faulty sentence structures

Wordiness, verbosity, redundant vocabulary, etc., that inhibit effective communication

Faulty punctuation use

The use of contextually inappropriate linguistic forms

Dangling modifications

The following sentences, randomly taken verbatim from some 'serious' Ghanaian newspapers, illustrate the nature of the problem under discussion:

\section{Headline: What about Ghana Institute of Journalism?}

Sentence: In the speech read by the deputy minister of education responsible for tertiary education, Dr. Joe Annan on behalf of the minister of education, Mr. Alex Tetteh-Enyo, during the launch of the fiftieth anniversary it was mentioned that the Institute has one of the best libraries in Ghana which is not the truth because out of the ten computers in the library only four are really functioning and the rest are just white elephants in the library.

\section{Headline: NPA dragged to court for illegal fuel prices}

Sentence: They are claiming against Defendant jointly and severally, a declaration that the ex-refinery differential component of the ex-refinery price imposed by the first Defendant on June 5, 2009, was illegal and that the ex-pump prices announced by the first Defendant on June 5, 2009, on the basis of the ex-refinery prices referred to, were not in accordance with prescribed petroleum pricing formula and therefore unlawful.

\section{Headline: AMA boss must be focused and resolute}

Sentence: As the ultimatum issued by the Accra Metropolitan Assembly (AMA) to squatters at Sodom and Gomorrah to provide evidence of legal occupation or vacate the area expired early this week with none of the squatters 
complying, there have been various news articles, press releases and statements from people whipping sentiments for the AMA to abort the eviction.

\section{Headline: IGP outlines vision}

Sentence: Key among these interventions, which aim to significantly improve the maintenance of law and order as well as the protection of life and property is to lead the Police Service to undertake a major internal restructuring and capacity building in order to utilize to maximum benefit, the limited human and logistic resources of the Service.

This paper did not set out to construct detailed and systematic analysis of grammatical errors of newspapers or their writing styles, since these fall outside the paper's objective (see the opening paragraph). Besides, incorrect English in the press has been established through research (see Karikari, 1998; Denkabe \& Gadzekpo, 1996) and often revolves around topical issues in public discussions (as indicated earlier). Therefore, the few examples above represent a little picture of the general way of writing and language challenges of many newspapers in Ghana. The first example is a mixture of errors involving capitalization, punctuation, tense, wordiness, and redundancy. Grammatical errors aside, it becomes difficult to understand the import of the author's message. The second example typifies a very technical legal rendition, which even this writer, with his level of education, found difficult to understand. The media is expected to mediate between specialised vocabulary and/or jargons, meaning, and a 'mass' readership. However, in this example under question, the journalist appears to be writing to impress instead of making sense to the reader. The third and fourth examples are also dotted with abstract and 'high' or difficult words and expressions, which will undoubtedly defy immediate understanding. Additionally, the sentences are long, displaying lexical and syntactic complexity: the first one has about 78 words; the second, 65; the third 57; and the last has 54. Indeed, a major linguistic characteristic of the majority of Ghanaian newspapers is the use of long, winding, jargon-riddled, abstract, and very complex words and sentences. 
Meanwhile, all worthy journalism or communications textbooks have, at least, a language section or chapter. This (language) section urges students as to the type of language expected of the field. According to Hicks, et al. (1999: 9), “Journalists are interpreters between specialist sources and the general public, translators of scientific jargon into plain English". Mckane (2006), Stovall (1990), and other writers on journalistic writing, argue for news writers to make news stories easily read and understood. Mass media writing should be clear, concise, simple, and to the point. These writers emphasise modest language, which should not draw attention to itself. Porter (2005), in a draft essay, argues for a redefining of the language of journalism and stressed "news as a conversation... which must remove the walls between the "producers" of news and the "consumers" of news. In this essay, Roy Peter Clark is also quoted thus, "The most valued quality of the language of journalism is clarity and its most desired effect is to be understood". Moreover, the press in a society like Ghana where English permeates as a second language may serve as a source for readers to learn English taking into account the challenging educational situation in the country. The point, obviously, is for news to be delivered in a language (English) that is as appropriate as possible within its socio-economic and educational context.

The pervasive grammatical challenges and the seemingly complex nature of newspapers' language appear to ask questions about the readership the papers are targeting. This is important, taking into account the need for almost every literate person in a developing country like Ghana to be informed, understand national issues, and participate in national discourse for development. This paper has intuitively conceptualised the "average" reader as a Junior High School (JHS) leaver, who, at an average age of between 15 and 17, deserves to understand what is happening in their country to prepare him or her for democratic participation at any level of his or her development. This conceptualisation is based on the understanding that almost all newspapers in Ghana are printed in English meaning that literacy is fundamental to accessing newspapers. Literacy here refers ordinarily to the linguistic and background knowledge needed to speak, read and write English in order to be socialised into the socio-economic and cultural dynamics of the 
country (issues of literacy in Ghana have been discussed extensively in Opoku-Amankwa \& Brew-Hammond [2011] and Owu-Ewie [2006]). In the context of this paper, literacy accordingly implies the ability to read and understand newspapers in the country. Furthermore, literacy is largely attained in the domain of formal education. The reality is that the developing status of Ghana reflects in low educational attainments at all levels of the country's educational structure. The above are all critical considerations that should underpin news writing.

However, one wonders if the sentences in newspapers (such as those cited above) can be easily read and understood by even the Senior High School (SHS) leaver. The scope of this study does not allow for detailed discussions of issues of education, literacy, etc. However, one can have a look at the annual reports on English language in the Chief Examiner's Report of the West African Examinations Council (WAEC) to appreciate this matter. In October 2009, there was a remarkable news headline in the Ghanaian Times, a state-owned newspaper. The headline read: "Pupils Fail BECE: They Can't Read." The lead of the story was:

The Adentan Municipal Director of Education, Rosemond A. Aduku, has blamed pupils' poor performance in the Basic Certificate Examination (BECE) on their poor reading and writing ability. (Monday, October 1, 2009: 15)

The implication is that the press can play a role in helping average students to learn by writing not only good English but also using a language that is relatively readable to such students. This should also expose and make such people develop interest and literacy in the political culture of the country.

Therefore, though there has not been much research on newspaper writing style and its impact, the media language (as seen above), and the educational realities in Ghana support the position that the newspapers appear to lack the language ability to appeal to and be easily read by a broad readership. How do we account for this? How do we deal with such a situation? The onus lies 
on journalism-training institutions in the country. Therefore, this paper calls for a second look at the English education given to students in journalism training institutions.

The point must be made that the discussions in this paper are based on the historical and general press situation in Ghana. From the pre-independence era when Ghanaians entered the journalism industry through independence to the present, the majority of journalists in the country have been Ghanaians (by chance and not by any legislative mechanism). Additionally, in the past decade or earlier, most of the journalists in the country and the various editors of newspapers have been products of the Ghanaian educational structure. In fact, many of the journalists in the country were educated at the Ghana Institute of Journalism (GIJ) in Accra (Hasty, 2005). Presently, there are a number of journalism training institutions all producing journalists most of whom work in the Ghanaian media industry. In her work, Hasty (2005) also observed the occurrence of what she describes as "Big English" in the Ghanaian press.

\section{Methods of enquiry}

Therefore, the paper examined and analysed the English language courses in four major journalism-training institutions in Ghana, as well as the English provisions in the latest UNESCO journalism curricula for Africa (2007), covering diploma and undergraduate programs. The idea is to determine the adequacy or otherwise of English studies in the schools to prepare students for their journalistic work. Semi-structured interviews with the Heads of English/Language Departments of the institutions under question were conducted to help construct an understanding of the matters raised in this paper.

\section{English education in journalism training institutions in Ghana}

Universities and their equivalents in Ghana admit regular students based on performances at the now West African Senior Secondary School Certificate Examinations (WASSCE). One criterion for admission is a pass in English (and other "core" subjects). The assumption is that a student who passes the WASSCE English has the language competence to study at the university level. 
Competence here refers ordinarily to having the linguistic knowledge to use language correctly (grammatically and structurally) across purposes, cultures, and readership. This also means that such a student can function effectively in English upon completion of his/ her course. The grades at the above examinations range from A, B, C, D, E, and F, the interpretation being Excellent, Very Good, Good, Fair, Pass, and Fail respectively (The old grading system for SSSCE has been used for convenience as it has the same equivalents in the new WASSCE system). The pass grades are A, B, C, D, and E. Apart from GIJ, which pegs its English requirement for both undergraduate and diploma admission at D or better, most other tertiary institutions in Ghana put theirs at E. Indeed some institutions even admit students who failed English language at the Senior High School level and require that they write and pass the subject before graduating.

The four institutions used for this study are Ghana Institute of Journalism, Accra (GIJ); African University College of Communications, Accra (AUCC); Jayee University College, Accra (JUC); and Institute of Business Management and Journalism, Kumasi (IBM \& J) $)^{\mathrm{i}}$. Of the four, GIJ is the only public institution; the rest are private. GIJ is (now) a public university established in 1959 purposely to produce media professionals in journalism, communications, and public relations. It runs diploma and undergraduate courses in communication studies and short courses in the same field. The majority of journalists in Ghana today attended this institution. AUCC, founded in 2001, also currently runs diploma and undergraduate programmes in journalism and communications including short refresher courses in communications and media studies. Its students have been working as professional journalists in Ghana. JUC runs diploma and undergraduate programmes in journalism. Finally, IBM \& $\mathrm{J}$ is a business institution that recently began a course in journalism. As such, the institution runs only a diploma course in journalism. There are journalists in the country today who graduated from these last two institutions as well. The objective of these training institutions is to produce professionals with the requisite knowledge and skills to function as journalists and communication professionals. In this way, the press would contribute to the democratic and socio-economic development of Ghana. As such, the institutions have a number of similar specific courses within broad domains including mass 
communication, news writing, broadcast journalism, print journalism, public relations and advertising, media and communication theories, TV and radio production and media law. The courses are designed to produce the expected calibre of journalists within the four (BA) and twoyear (diploma) durations.

The courses at the various levels are too many and varied to cover here. Therefore, since the study is focusing on English, it will be more helpful to focus on English language courses and other courses not English language per se but related to English. The courses are classified as "core" and "elective and/or ancillary", either directly or impliedly. English is classified as an ancillary course. This categorisation has some implications. Core courses are supposedly very important and key to the qualification and later performance of the student. However, the elective and/or ancillary ones, being outside the inner circle of the programme, are by implication less vital so could even be optional. Thus, elective and/or ancillary courses are perceived as peripheral and appear not to be treated seriously.

\section{English language for undergraduate programmes}

In the three institutions that offer the BA qualification, all the English or English-related courses fall among the elective and/or ancillary courses. Even though students have to pass them to graduate, they are seemingly not viewed as key courses. The table below gives graphic details of English courses in the schools for comparative convenience:

Figure 1: Table 2: Undergraduate English Courses at the Institutions

\begin{tabular}{|c|l|l|l|}
\hline GIJ & AUCC & JUC & IBM \\
& & & \& J \\
$\bullet$ Language and & $\bullet$ Foundation of & $\bullet$ English & \\
Study Skills & grammar & Grammar & \\
(a level $\mathbf{1 0 0}$ & $(\mathbf{a}$ level $\mathbf{1 0 0}$ & $\bullet$ Creative Writing & N/A \\
\hline
\end{tabular}




\begin{tabular}{|c|c|}
\hline $\begin{array}{l}\text { course for } 2 \\
\text { semesters) } \\
\text { - Precision } \\
\text { Language } \\
\text { (a level } 100 \\
\text { course for } \\
\text { only the } 2 \\
\text { semester) }\end{array}$ & $\begin{array}{l}\text { course for the } \\
\mathbf{1}^{\text {st }} \text { semesters) } \\
\text { - Foundations of } \\
\text { writing } \\
\text { (a level } 100 \\
\text { course for the } \\
2^{\text {nd }} \text { semesters) } \\
\text { - Lab. Work (all } \\
\text { the four years) }\end{array}$ \\
\hline
\end{tabular}

Sources: GIJ: GIJ Students Handbook, 2008

AUCC: Interview with Head of English Department, AUCC

JUC: Components of Courses for all Programmes, (brochure, 2008)

From the table above, it is evident that GIJ does not run any pure English language course for the four-year undergraduate programme. Language and Study Skills (LSS) or Academic Writing does not really teach English; it teaches students the language-related skills such as note taking/making, outlining, paragraphing, composition writing, documentation, etc., which are competencies needed for tertiary level studies. Precision Language also essentially revises correct usage of the parts of speech, tenses, preposition, etc.

AUCC has two English related courses -- Foundations of Grammar and Foundation of Writing, which simply revise some aspects of the SHS English much the same as the two courses at GIJ. The courses take place only at level 100. Additionally, AUCC has a course, Laboratory Work, which is English-based and runs each semester of the four years. This course does not have any systematic outline as it is only meant to strengthen students' English competence. Thus, the content at each level and semester depends on the lecturer. The lecturer gives random English usage exercises and takes the students through identifying their errors and correcting those errors. JUC has one English course, Grammar, which runs during the two semesters of level 100. Creative Writing, taken in the Department of Journalism, covers writing and literature.

\section{English language for diploma programmes}


The diploma programmes in the cited institutions provide a rather interesting variation. The subjects are not classified in terms of core and ancillary in all the institutions, and students have to pass every course in order to graduate. Additionally, students study English each semester of the two years. The table below shows the distribution of English language and English-related courses at the diploma level. Each course has a two-hour duration per session:

Table 2: Diploma English Courses at the Institutions

\begin{tabular}{|c|c|c|c|}
\hline $\begin{array}{l}\text { GIJ } \\
\text { - English } \\
\text { Grammar } \\
\text { and } \\
\text { Usage } \\
\text { (for each } \\
\text { of the } 4 \\
\text { semesters } \\
\text { ) } \\
\text { English } \\
\text { Writing } \\
\text { Skills } \\
\text { (for each } \\
\text { of the } 4 \\
\text { semesters } \\
\text { ) }\end{array}$ & $\begin{array}{l}\text { AUCC } \\
\text { - Foundations of } \\
\text { Grammar } \\
\text { - Foundations of } \\
\text { Writing } \\
\text { (for each of } \\
\text { the } \\
\text { semesters) } \\
\text { Lab. Work } \\
\text { (runs the } 4 \\
\text { semesters of } \\
\text { the } 2 \text { years) }\end{array}$ & $\begin{array}{l}\text { JUC } \\
\text { - English Grammar } \\
\text { (only the } \mathbf{1}^{\text {st }} \\
\text { semester of Dip. } \\
\text { 1) } \\
\text { - Comprehension \& } \\
\text { Summary } \\
\text { (only the } \mathbf{2}^{\text {nd }} \\
\text { semester of Dip. } \\
\text { 1) }\end{array}$ & 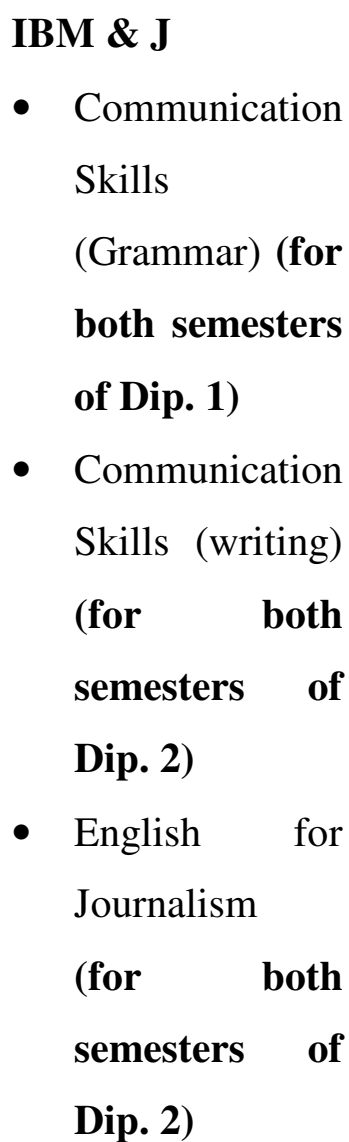 \\
\hline
\end{tabular}

Sources: GIJ - GIJ Students Handbook, 2008

AUCC - Interview with Head of English Department, AUCC.

JUC - Components of Courses for all Programmes, (brochure, 2008)

IBM \& J - Institute's Programme flier 
Of the institutions under study, GIJ teaches four hours of English per week for the diploma programme for the two years. AUCC has six hours, i.e. including Laboratory Work for the four semesters the way it is for the undergraduate programme. JUC, however, has only two courses, which take place only in diploma 1: Grammar is taught during the first semester while Comprehension \& Summary takes place in the second semester. Thus JUC teaches English four hours a week for only year one. IBM \& J teaches Communication Skills (English Grammar and Writing) throughout the two years of study, Grammar in year one, and Writing in year two. This School also teaches English for Journalism, which covers journalese in both semesters of diploma two. This means that the institution has two hours of English teaching in the $1^{\text {st }}$ year and four hours in the $2^{\text {nd }}$ year.

The institutions also run other courses such as feature writing, creative news writing, writing for the radio and TV, reporting and writing, etc. at both undergraduate and diploma levels, which look like English. However, their contents depict otherwise, and departments other than English run the courses. This opens up an unexplored avenue for collaboration between the English departments and the departments concerned to reinforce the students' language since in journalism language is not used for its own sake but for specific journalistic purposes.

\section{Implications for English teaching and learning}

One point is clear: the classification of English as an "elective" or ancillary course means that school authorities do not regard English as crucial in the training process. It follows therefore that students also think of it as a course to pass in order to graduate and not something "to waste time on". The question to ask is whether the English courses displayed above are adequate in terms of perception, content, and duration to prepare students with English challenges for a job in journalism. In fact, there has been little systematic research on the content, structure, length, and duration of English teaching and learning needed to enhance the English language competence of students in tertiary institutions in Ghana. However, taking into account the serious challenges facing basic and secondary education in Ghana, particularly regarding English 
teaching and learning (Fosu, 2009), it is normal to expect that students will continue learning the language throughout their years in journalism institutions. The reality is far from this expectation.

Nevertheless, it is commendable that GIJ and AUCC have four and six hours respectively of English studies per week for the diploma. It shows that the two institutions reckon with the importance of English and are taking steps to address the problem. JUC, however, teaches two hours of grammar in the first semester of diploma 1, and two hours of comprehension and summary in semester two, which is not adequate for the diploma programme. Interestingly, JUC's Comprehension \& Summary is unique because of the language benefits to be derived from such a course, if it is effectively taught. And IBM \& J's two-hour Grammar for only the $1^{\text {st }}$ year and the two-hour Writing Skills for only the $2^{\text {nd }}$ year may not be adequate.

However, the situation is generally grim for the undergraduate programmes. GIJ does not teach any outright English course. Even if the LSS and Precision Language programmes are considered as English courses, they together produce about 84 hours of English studies for the whole four years ${ }^{\mathrm{ii}}$ of the undergraduate programme -- this is not taking into consideration time lost through lecturer illness and institution vacations. The situation is almost the same for JUC and AUCC. AUCC's Laboratory Work course gives an indication that this school is taking some measures to combat the challenge.

\section{Course content of the programmes}

It is important to note that all the English and English-related courses discussed above largely revise standard English usage as taught in secondary school. It is not surprising that some of the course titles reflect this: English Grammar and Usage, Grammar, Communication Skills, Summary, and comprehension, etc. (see Fosu, [2009] for a detailed discussion of this issue). Additionally, the schools, from the investigations of this researcher, do not have any systematic language teaching methodology that informs English teaching and learning. The teaching 
technique appears to be based largely on the teacher's personal initiative of using the unhelpful grammatical approach, rather than the more helpful communicative approach to language learning (see Dzameshie, 1997). The above scenarios cannot guarantee any significant improvement in the student's English over the programme period. This implies that a student can achieve, in relative terms, only marginal improvement in his or her English taking into account his or her English competence at the senior secondary or before he or she was admitted to any of the institutions.

Another dimension of the above discussion is the different labels, course content, course structure, duration, etc. of the courses in the four institutions. These institutions produce journalists and communication experts for the same industry and therefore one would expect them to run near homogeneous programmes. Indeed, three of these schools are in Accra, primarily feeding the same market. Therefore, it will be difficult to have a generally uniform conception of the English competence of those who graduate from these institutions.

It is also clear that the institutions appear to emphasise English teaching and learning in the diploma programmes much more than in the undergraduate ones. This situation could imply that the school authorities consider the undergraduate students as academically superior in English to the diploma students, perhaps because of the weight of the respective final qualifications. This argument, however, is not sustainable in terms of English ability since both categories of students go through the same pre-university educational system (which, as discussed earlier, is fraught with English teaching and learning challenges). In addition, both prospective undergraduate and diploma students have the same English criteria for tertiary level admissions. Therefore, going by the paucity of English studies at the undergraduate level, and the fact that all English courses at both the diploma and undergraduate levels only revise what students should have perfected at SHS, one can conclude that the institutions under-rate language in the training process, especially at the undergraduate level. What is more, none of the institutions has a 
language laboratory for language studies. This writer, being a tertiary-level English teacher, has a fair idea of the constraints in English teaching in tertiary institutions in Ghana.

\section{The UNESCO Model Curricula for Journalism Education}

The UNESCO Model Curricula is a unique and seminal document that covers journalism training at the postgraduate, undergraduate, and diploma levels (http://unesdoc.unesco.org/images/0015/001512/151209E.pdf). The aim of the curricula is to produce journalists with the desired knowledge, skills, and tools of journalism for them to engender development in their communities. The document covers 2-year masters, 3-yr and 4year undergraduate, two-year and one-year diploma programmes and provides options for arts and science backgrounds.

Importantly, the document does not just acknowledge the importance of language competence in journalism; it actually demonstrates this in the language and language-related courses advocated at all levels and semesters of the undergraduate and diploma programmes.

The document details the language skills expected of a journalist:

- An ability to write accurately, clearly, correctly, concisely and engagingly, in journalism story forms, with attention to subject matter and intended audience, always making clear the source of a disputable item of information, idea or direct or indirect quotation (p. 9).

The document has ample language provision covering grammar and syntax, narrative, descriptive, and explanatory methods, among others, all tailored to produce an individual with the requisite English and writing skills to write across journalistic purposes.

\section{Interviews with heads of the various English departments}


The Heads of Department (HODs) of English of GIJ, AUCC and JUC were purposely sampled and interviewed. As heads of the language departments, they were in a good position to provide an insight into issues concerning English teaching and learning in their respective schools. Among others, the semi-structured interview posed and discussed questions such as:

- What is your opinion of English usage in the media?

- What do you think of the English ability of students in your institution?

- How do you account for this situation?

- Would you say that students in your school have the best opportunity and facilities to study English?

- What can be done to stem the tide of poor English in our journalism schools?

Although the interviews took place separately, the responses were remarkably similar. All the HODs expressed grave worry about the poor and steady decline of English in the media, especially the print media. Their worry stemmed from a view shared by this writer that the mass media have the biggest number of "students" and so if bad English continues in the newspapers in an educationally challenged country like Ghana, the educational function of the media becomes compromised. The HODs were again unanimous on the poor English of the students in their respective schools. On the causes of this situation, the HODs blame the admission process of their respective institutions arguing that, "garbage in, garbage out." Some blamed the students and the schools. They said students were not reading enough to boost their English, and the schools too had not provided appropriate opportunities such as adequate contact hours and teaching and learning facilities for language learning.

On ways of improving on the situation, some called for stringent admission processes to ensure that quality students are enrolled. Some also suggested remedial classes for weak students. In fact, at JUC, the HOD had already started efforts to improve the situation. 
He told this writer of new English-related courses -- academic writing and writing skills -- to be introduced for both diploma and undergraduate programmes. They also suggested practical opportunities such as college newspapers, writers' clubs, etc. to help students in learning English. Some confided in this writer that their university authorities ignored or paid little attention to their suggestions on steps to improve language teaching and learning because language is not a key component.

The information from the two interview categories above supports the original hypothesis of this paper on the poor state of English in the media, particularly print. Through their responses, it is evident that the students themselves know they have English problems and want to have more opportunities to study the language in school. This also implies that as professional journalists the students are likely to have performance handicaps in English on the job. The 10 students interviewed may not be a fair representation of journalism students in Ghana but their responses provide an idea of the problem based on which further more specific research may be conducted. The Heads of English Department have also indicated not only their awareness of the problem but also the causes and remedies. It means the problem persists because of a lack of action on the part of the institutions to stem the tide. Therefore, it appears the institutions are not doing enough to address the situation, meaning that by not being pro-active, the journalism schools are instead entrenching the language problems in the media.

\section{Discussion: Broadening the spheres of English teaching and learning}

The aim of any journalism education is to train students to acquire the requisite journalism knowledge and skills as well as the tools to perform their expected functions in their societies. This objective and competencies expected of products of journalism schools are best summed up by the following considerations that informed the UNESCO Curricula (2007: 7):

Journalism education in universities is normally organised around three curricula axes or lines of development:

i. An axis comprising the norms, values, tools, standards, and practices of 
journalism;

ii. An axis emphasising the social, cultural, political, economic, legal, and ethical aspects of journalism practice both within and outside the national borders; and

iii. An axis comprising knowledge of the world and journalism's intellectual challenges.

The UNESCO document further clarifies that graduates of journalism schools should have "An ability to write clearly and coherently using narrative, descriptive, and analytical methods" (emphasis mine).

Of the above expected knowledge and skills, this paper argues that the cardinal competency should be excellence in linguistic competence in English. It could be argued that a person who graduates as an accountant, and has English problems, may still perform his accounting functions well, even if in bad language. Therefore, unlike other professions like engineering, agriculture, etc. it is only through language that the journalist can manifest the knowledge and skills learnt; it is only through language that the journalist can present information he or she has used his knowledge and skill to garner to a targeted audience.

Many reasons have been adduced as to why development communication along the lines of innovation diffusion and other modernisation approaches in deprived areas have not made the desired impact (Okigbo \& Eribo, [2004]; Melkote \& Steeves, [2001]; Waisbord, [n.d.]; etc.). One major factor has been the over reliance on technology transfer that did not consider the sociocultural and demographic conditions on the ground. When discussing development communication, little attention often appears to be paid to the role that knowledge plays in empowerment toward development. Any development paradigm, policies, and implementation efforts should involve the active participation of the development beneficiaries. These people should understand the issues at stake to be able to get involved. 
That is why this paper argues that equipping the people with the required knowledge and enlightenment toward this end is a crucial step. Therefore, the media's role in the provision of knowledge constitutes development communication for which reason this paper argues that media people have the language ability to reach the broad masses of the people in order to hasten the development process.

It is the considered opinion of this paper that the way forward lies in journalism training institutions uniformly following curricula along the lines of the UNESCO model, emphasising the language and language-related courses. This should pave the way for journalism education in Ghana to revolve around language as a search for improved (English) language ability in journalistic writing. A more worthwhile complement will be to de-emphasise the "core" journalism or media knowledge and skills students are made to focus on and rather emphasise language studies for journalism. Society does not "consume" the knowledge and skills the journalist studied; society, it is argued, rather depends on linguistically well-packaged information (that the journalist used his or her knowledge and skills to gather). This is not to devalue the "core" courses; the idea is to ensure that the skills and knowledge the would-be journalist gains in school find practical expression and come to life through language. There is therefore the need to broaden the spheres of English in the teaching process. How do we do this?

In following the precepts of the UNESCO Model Curricula, the institutions could design teaching and learning content that reflect the needs of the peculiar Ghanaian socio-cultural realities for development. Additionally, there is the need to ensure that schools do not limit English studies to diploma programmes. Undergraduate students should also study English or an English-related course at least each semester of the four or three years to guarantee adequate English learning opportunities. Journalism schools ought to stop treating English as a peripheral or ancillary course to prevent the psychologically negative attitude of students towards the subject. English should be made a core journalism course and should be thought of and given attention as such. 
It is also argued that journalism institutions should enforce quality control in their admission processes. Perhaps the admission criterion that students should pass the SSS English to be admitted to tertiary institutions could account for why it appears the schools do not pay the needed attention to English teaching and learning at the undergraduate level. The understanding could be that such students are good at English once they have passed the SSS English paper. However, the fallacy of this assumption is the pervasive poor English displayed in the media.

Obviously therefore, students who enroll in the journalism institutions still have serious English problems irrespective of the WASSCE English grades they came with (whether A or E). Hence, it is imperative that all tertiary students of any programme take intensive and adequate English studies to prepare them for the communicative aspect of whatever job they leave school to perform. Teaching in the schools should adopt an integrated approach where courses involving writing would be handled collaboratively by teachers from both the English department and from the department of the courses. This would make students understand the direct and practical relevance of language in journalistic work.

This paper argues that the content of the English courses in the schools is inadequate to produce competent individuals in English who understand the workings of language for application in journalistic writing. In a paper presented at the Conference of African Journalism Educators (CAJE), Edward Chitsulo (2009) argued that, "where possible, the study of language as a science should not be an option". This paper agrees that journalists in training should study English beyond the revision of what obtains at the Senior Secondary level. As such the curriculum should be constructed to expose students to the following language areas even within the modules suggested in UNESCO Model.:

- language levels (formal and informal)

- $\quad$ stylistic implications of grammatical forms

- general stylistics

- linguistics 
- semantics

- $\quad$ varieties of English

- sociolinguistics

- $\quad$ the new Englishes (Ghanaian English, Nigerian English, etc.)

- literature and creative writing

- etc.

Regarding teaching methodology, it is becoming increasingly clear that the lack of a systematic approach to English teaching in our schools is not helpful, especially in a situation of large classes. Thus, efforts should be made to develop an English teaching method of teaching for journalism schools targeted at achieving the following competencies:

- knowledge of linguistic features

- knowledge of discourse rules

- knowledge of language functions

- knowledge of sociolinguistic factors, and

- knowledge of appropriateness, which enables a speaker to know whether the language being used is suitable considering the specific (socio-cultural) context and audience.

In terms of facilities, it is suggested that each training institution should establish a wellequipped language centre. The centre should be well resourced to run various language courses throughout the year. Some of the courses could merge into the mainstream journalism programmes while others run parallel to the regular journalism courses. Thus, students can have individual remedial brush-ups or register and take courses to beef up their language. The schools should also make idea-generating equipment such as cameras available for students to have opportunities to practise writing. With such gadgets, students could, for example, videotape events or take pictures of events and objects and practise writing vividly about them. 
Additionally, the institutions should provide outlets such as institutions' own newspapers, writers' clubs, school magazines, etc. for students to write and have their stories published. Such activities will motivate writing and provide material for class discussions, which will straighten rough edges before the students begin to work.

\section{English teachers in journalism schools}

It would also be a great idea for English teachers in journalism schools to have periodic conferences to brainstorm about fruitful ways of teaching to maximise students' learning. Additionally, the schools should provide opportunities and encourage English teachers to take up journalism courses to understand the nature of the profession and be in a better position to guide students in the language. Opportunities need to be explored for English teachers in journalism in Ghana and Africa to meet periodically and strategise in order to achieve better outcomes on the job.

\section{Conclusion}

This paper began with the premise that the writing style of some Ghanaian newspapers displays serious English problems, which could potentially impede communication. The need to identify some, if not all, of the problems was what motivated the study of the English courses of the four institutions. The paper has established that English study in the four journalism-training institutions in terms of contact hours and content is generally inadequate and unhelpful and that the situation is more serious at the undergraduate level. There is therefore the need to revolutionise English teaching and learning in Ghanaian journalism-training institutions.

The study has identified the problem and made a few suggestions. No research has been done to determine the appropriate English programmes (contact hours and content) for tertiary institutions in Ghana. It is the view of this paper that most parts of Anglophone Africa, particularly West Africa, share many similar developmental characteristics, one being this language problem in the media. Therefore, the call to improve English teaching and learning in journalism schools goes beyond Ghana. 
This paper urges scholars and professionals in the media industry to discuss specific ways of uniformly improving journalistic writing, beginning in the training institutions. The desire is to produce journalists who have the capacity to write in a way that attracts reading and is accessible to every newsreader.

English in the Ghanaian print media speaks volumes about the state of the country's educational and development status. The media are, undoubtedly, an important "teacher" in our societies because of their reach. Many people consciously or unconsciously learn English in the media. Thus, our journalists must be good English educators through their language. According to the UNESCO document: "Students should emerge from a diploma program well versed in the basic techniques and forms of journalism reporting and writing" (p. 32). Therefore, to put Ghanaian and African journalism on the world map and for journalism to fulfil its functions, journalism institutions ought to refocus and restructure their curricula to emphasise English usage and thus empower and inspire journalists to champion the cause of democracy and development.

\section{About the author:}

Modestus Fosu is a lecturer at the Ghana Institute of Journalism, Accra, Ghana.

Email: fmodestus@hotmail.com

\section{References}

Awidi, I. T. (2008). Developing an E-Learning strategy for public universities in Ghana. Retrieved 12 April 2010 from the World Wide Web; http://creativecommons.org/licenses/by-ne$\mathrm{nd} / 3.0 /$

Chitsulo, E. (2009). Language and presentation gaps in print media: The case of Malawi:

Possible remedy at tertiary levels? Paper presented at the Conference of African Journalism Educators, WITS University, Johannesburg, South Africa: 23-25 October, 2009. Retrieved 21 April 2009 from the World Wide Web: http://www.journalism.co.za./image/april2009/languages

Daily Graphic. (October 2008; October 2009). Accra: Graphic Communications Ltd.

Dako, K., Denkabe, A., \& Forson, E. B. (1997). The Ghanaian university students' knowledge of grammar. In Dakubu, M. E. K. (Ed), English in Ghana. Accra: Ghana English Studies Association. 
Dakubu, K. M. E. (Ed). (1997). English in Ghana. Accra: Ghana English Studies Association.

Denkabe, A. \& Gadzekpo, A. (1996). What is fit to print? Language of the press in

Ghana. Accra: Ghana Universities Press.

Dzameshie, A. K. (1997). Towards a communicative approach to teaching English as a second language in Ghana. In Dakubu, M. E. K. (Ed). English in Ghana. Accra: Ghana English Studies Association.

Eribo, F. \& W. Jong-Ebot. (Eds). (1997). Press freedom and communication in Africa. Asmara: African World Press.

Fosu, M. (2010). Towards a language policy for journalistic practice in Africa. Paper presented at the Conference of African Journalism Educators, 2009, WITS University, Johannesburg, South Africa, 23 - 25 October, 2009. Retrieved 21 April 2009 from the World Wide Web: http://www.journalism.co.za./image/april2009/languages

Fosu, M. (2009). English in tertiary institutions and the issue of falling standards: expectations, lessons and challenges. Journal of Communications, Media \& Society, 1(1): 21-28. Accra: Ghana Institute of Journalism.

Hicks, W. (1999). Writing for journalists. London: Routledge.

Hasty, J. (2005). The press and political culture in Ghana. Bloomington, Indiana: Indiana University Press.

Inkeles, A. \& Smith, D. H. (1974). Becoming modern. Cambridge, MA: Harvard University Press.

Kellner, D. Habermas, the public sphere, and democracy: A critical intervention. Retrieved 21 April 2010 from the World Wide Web: http://www.gseis.ucla.edu/faculty/kellner/kellner.html

Karikari, K. (1998). The press and the transition to multi-party democracy in Ghana. In: K.A. Ninsin, (Ed). Ghana: Transition to democracy. Dakar: Codesria.

McQuail, D. (2005). Mass communication theory. London: Sage Publishers.

Mckane, A. (2006). News writing. London: Sage Publications.

Melkote, S. R. \& H. L. Steeves. (2001). Communication for development in the Third World: 
Theory and practice for empowerment. New Delhi: Sage Publications.

Okigbo, C. C. (2004). The African world: The publics of African communication. In: Okigbo, C. C. \& Eribo, F. (Eds). Development and communication in Africa (Pp. 31-43). Lanham: Rowman \& Littlefield Publishers..

Opoku-Amankwa, K \& A. Brew-Hammond. (2011). Literacy is the ability to read and write English: Defining and developing literacy in basic schools in Ghana. In: International journal of bilingual education and bilingualism. Vol. 14 (1): 89-106.

Okigbo, C. C. \& F. Eribo. (Eds). 2004. "Introduction" In: C. C. Okigbo and F. Eribo, (Eds), Development and communication in Africa. Lanham: Rowman \& Littlefield Publishers.

Owu-Ewie, 2006. "The language policy of education in Ghana: A critical look at the Englishonly language policy of education." In J. Mugane et al., (Eds). Selected proceedings of the $35^{\text {th }}$ annual conference on African linguistics. Somerville. M. A.: Cascadilla Proceedings Project (pp. 76-85).

Porter, T. (2005) Newspapering, readership \& relevance in a digital age: Redefining the language of journalism. Retrieved 30 April 2010 from the World Wide Web:

http://www.timporter.com/firstdraft/archives/000409.html

Rogers, E. M. (1983). Diffusion of innovation ( $3^{\text {rd }}$ ed.). New York: Free Press.

Schramm, W. (1964). Mass media and national development: The role of information in the developing countries. Stanford, CA: Stanford University Press.

Stovall, J. G. (1990). Writing for the mass media. NJ: Prentice Hall.

The Chronicle. (September 2009). Accra: General Portfolio Limited.

The Ghanaian Times. (May, September 2009). Accra: New Times Corporation.

The Statesman, (24 April 2009). Accra: Kinesic publications:

http://www.thestatesmanonline.com/pages/links.php\#

Thompson, N. M. (2008). Whither Ghanaian journalism? Daily Graphic, 27 October 2008. Accra: Graphic Communications Ltd.

UNESCO, (2007). Model curricula for journalism education for developing countries \& emerging democracies. Retrieved March 2010 from the World Wide Web: http://unesdoc.unesco.org/images/0015/001512/151209E.pdf 
Waisbord, S. (n.d.). Family tree of theories, methodologies and strategies in development communication. Retrieved 16 February 2010 from the World Wide Web:

http://www.rdfs.net/themes/communication_en.htm

\section{Endnotes}

i For more information about the institutions visit their websites:

- African University College of Communications : www.aucc.edu.gh

- Ghana Institute of Journalism : www.gij.edu.gh

- Institute of Business Management \& Journalism

- Jayee University College : www.jayeeuniversity.com

ii That is, two hours of LSS for 14 contact hours per semester for two semesters, and two hours of Precision Language for 14 contact sessions for one semester. 